\title{
GEJOLAK RESISTENSI DALAM SELF-FASHIONING LEILA S. CHUDORI: CERPEN “PARIS, JUNI 1988"
}

\author{
Sari Fitria \\ S2 Ilmu Sastra UGM \\ Email: lieverdshari@gmail.com
}

\begin{abstract}
Abstrak
Tujuan penelitian ini adalah mengungkapkan bentuk subjektivitas dan otobiografi Chudori sebagai bentuk resistensi melalui pengkajian self-fashioning yang terdapat dalam cerpen "Paris, Juni 1998". Penelitian atas self-fashioning pada cerpen tersebut dilakukan dengan menganalisis teks-teks yang ada secara induktif dan kemudian menggunakan konsep travel writing dari Carl Thompson. Hasil dari penelitian ini menunjukkan bahwa self-fashioning dalam cerpen Paris, Juni 1998 nampak dalam bentuk Cartesian dan Janus-faced, dimana dalam bentuk Cartesian subjektivitas Chudori dimunculkan melalui impressive dan trusthworthy, sedangkan dalam bentuk Janus-faced ditemukan otobiografi Chudori yang muncul dalam bentuk inward scrutiny dan persona.
\end{abstract}

Kata kunci: travel writing, self-fashioning, subjektivitas, otobiografi, Cartesian, Janus-Faced.

\begin{abstract}
The purpose of this research is to reveal the subjectivity and autobiography of Chudori as a kind of resistance through a study of self-fashioning exiting in a short story "Paris, Juni 1998". The self-fashioning study in this research is done by analyzing the text inductively and the applying Carl Thompson's travel writing concepts. The result of this research shows that the self-fashioning in Paris, Juni 1998 is a kind of Cartesian and Janus-faced. The Cartesian indicates that Chudori's subjectively is seen as impressive and trustworthy; mean while in Janus-faced we can see scrutiny and persona in Chudori's autobiography.
\end{abstract}

Keywords: travel writing, self-fashioning, subjectivity, autobiography. Cartesian, Janus-Faced

\section{Pendahuluan}

"Seperti suasana jalan panjang Champs Elysses, gadis itu merasakan bagian Paris yang ribut, arogan, dan tak ramah"

(Penggalan narasi dalam cerpen Paris, Juni 1988)

Kalimat di atas menggiring pembaca pada satu deskripsi atas suatu tempat/daerah di Paris. Champ Elysses bagian Paris yang ribut, arogan, dan tak ramah, merupakan satu kesan subjektif yang dibentuk dari pemaparan Choduri dalam cerpennya. Hal ini tentu berbeda dengan kebanyakan orang yang menganggap Paris sebagai kota yang indah, terutama mereka yang menjadi korban byperreality atas sebuah informasi mengenai Paris yang diperoleh dari bacaan, iklan, film, dan foto-foto yang memamerkan kemewahan Paris. Keindahan dan kemewahan kota Paris juga menginspirasi banyak pengarang untuk menjadikan Paris sebagai latar tempat dalam novel mereka, khususnya novel yang bergenre romantic, salah satunya novel terkenal yang ditulis oleh Margareth Richi, "Paris Kiss". Setidaknya, Paris sebagai kota yang indah dan romantis inilah yang ditawarkan Paris pada seluruh dunia. Namun, bagi seseorang yang pernah mengunjungi Paris tentu mempunyai deskripsi yang sama mengenai Paris atau bahkan berbeda dengan informasi pada umumnya. Bagi peneliti hal ini menjadi deskripsi yang bersifat baru bagi pembaca yang belum pernah 
ke Paris di samping posisinya yang mencoba menggambarkan Paris dari sisi yang berbeda.

Paris hanyalah representasi ruang dari sebuah perjalanan. Pada intinya, sebuah perjalanandarisatutempatketempatlainnyayang memiliki kultur berbeda akan mempengaruhi seorang traveller dalam mendefinisikan berbagai hal ketika ia menuliskan perjalanannya. Hal ini bisa dilihat dari hasil penelitian yang dilakukan oleh Akhiles Kumar yang berjudul Travel Writing and Empire: A Study of Conrad's Heart of Darkness. Dalam penelitian ini, Kumar melihat karakteristik-karakteristik travel writing yang terdapat dalam Heart of Darkness. Kumar juga mengaitkan penelitiannya ini dengan posisi pengarang (Conrad) yang juga merupakan seorang traveller dari satu tempat ke tempat lainnya yang memiliki kultur berbeda. Dalam hasil penelitiannya, Kumar menjelaskan bahwa perjalanan yang pernah dilakukan Conrad mempengaruhinya dalam menulis Heart of Darkness.

Oleh karena itu, dalam sebuah travel writing dapat ditemukan aspek otobiografi di dalamnya karena travel writing bisa menjadi sebuah eksplorasi bagi traveller untuk menampilkan kepribadian dan subjektivitasnya (Thompson, 2011: 7). Salah satu cara untuk mengungkapkan aspek otobiografi dan subjektivitas dari seorang traveller bisa dilihat dari bentuk self-fashioning yang secara implisit muncul dalam travel writing yang ditulisnya. Bentuk self-fashioning ini juga bisa ditemukan dalam cerita pendek Paris, Juni 1988 yang ditulis oleh Leila S. Chudori. Chudori menyelesaikan cerpen Paris, Juni 1988 ketika ia berada di Paris dan Jakarta dalam rentang waktu antara 1988 hingga 1989. Jadi tampaklah bahwa Chudori merupakan seorang pengarang yang juga seorang traveller. Ia juga merupakan seorang wartawan yang berkesempatan mewakili Indonesia mendapatkan beasiswa untuk menempuh pendidikan di Lester B. Pearson College of the Pacific di Victoria, Kanada. Selama masa studinya inilah, Chudori berkesempatan melancong ke Paris selama beberapa kali. Pengalamannya sebagai traveller ini banyak dituangkan dalam bentuk fiksi, baik itu novel maupun cerpen. Sekali lagi, ini menekankan bahwa ia telah melakukan perjalanan ke tempat dengan kultur yang berbeda.

Aspek otobiografi dan subjektivitas adalah dua hal yang berkaitan erat dengan self-fashioning. Lantas bagaimana bentuk self-fashioning yang ditampilkan Chudori dalam cerpen Paris, Juni 1988? Untuk menjawab pertanyaan tersebut, analisis terhadap cerpen ini bisa dilakukan dengan menggunakan konsep tentang revealing the self dalam perspektif travel writing dari Carl Thompson yang berkaitan dengan self-fashioning. Konsep Thompson mengenai revealing the self ini berakar dari pembacaannya terhadap travelogue Bill Byrson yang berjudul The Lost Continent (1989). Menurut Thompson (2011: 96-97), The Lost Continent tidak hanya merupakan literal travels dari pengarangnya, tapi juga perjalanan emosional dan psikologikal yang ada di dalam diri si pengarang. Hal ini setara dengan yang dikatakan Byrson dalam Thompson (2011: 96) bahwa setidaknya melalui travelogue mereka, para travellers telah membuat semacam penemuan diri. Inilah yang akhirnya menjadikan travel writing juga berkembang sebagai 'vehicles' untuk tulisan otobiografi. Hal ini bisa ditunjukkan dengan tampaknya self-fashioning dari pengarang yang muncul secara implisit di dalam tulisannya.

Melalui analisisnya terhadap karya Addison yang berjudul Remarks on Italy dan karya Releigh, Discoverie of the Large, Rich, and Beautiful Empyre of Guana, Thompson memformulasikan bahwa tulisan perjalanan mungkin saja berfungsi sebagai salah satu bentuk self-fashioning yang memberi peluang kepada pengarang untuk membentuk dan menyusun identitas khas mereka (Thompson, 2011: 105-106). Self-fashioning ini bisa muncul karena perjalanan yang dilakukan pengarang yang saat itu bisa saja menjadi grand tourist, pilgrims dan questing knights. Grand tourist merupakan suatu perjalanan yang dilakukan 
seorang traveller, seperti Addison, dalam rangka mengunjungi dan menikmati suatu tempat dari segi sejarah, budaya dan kulturnya. Sementara itu, pilgrim, seperti yang dilakukan Raleigh, merupakan suatu perjalanan yang awalnya bertujuan untuk memperluas kekuasaan Inggris, namun pada prosesnya tujuan ini gagal dicapai. Namun Raleigh mampu mengubah kegagalan ini menjadi sebuah keuntungan dengan menjadikan perjalanannya sebuah ekspedisi yang mampu mempengaruhi dan mengubahnya secara emosional. Pengalaman Raleigh ini juga bisa bertransformasi menjadi questing knight ketika protagonis dalam ceritanya digambarkan sebagai orang yang rela menghadapi berbagai rintangan dan ketidaknyamanan demi mencapai sebuah tujuan yang mulia.

Ada beberapa strategi yang bisa digunakan pengarang dalam melakukan self-fashioning di dalam tulisan perjalanan mereka. Pertama, travel writer mencoba menampilkan diri mereka sebagai seorang Cartesian (subjectivities) yang impressive dan trustworthy dalam menggambarkan dunia luar. Dalam hal ini, seorang traveller tidak hanya mengobservasi, namun juga bereaksi terhadap scenes yang ada di sekeliling mereka, lalu mereka akan merekam reaksi-reaksi tersebut dan merefleksikannya dalam tulisantulisan (Thompson, 2011: 117). Pada bagian ini, subjektivitas traveller akan tampak dalam tulisan-tulisannya.

Kedua, menampilkan tulisan perjalanannya dalam bentuk otobiografi yang juga merupakan aktivitas yang disebut dengan Janus-faced. Aktivitas Janus-faced ini melihat dua direksi secara bersamaan. Di satu sisi, ia mensyaratkan adanya inward scrutiny-suatu keadaan ketika pengarang mencoba mencapai sebuah pemahaman diri. Namun di sisi lain, terdapat persona (desired identity) yang ingin ditampilkan pengarang kepada pembaca. Maka dalam hal ini, aspek otobiografi dalam travel writing bisa tampak dari bentuk narasi yang disampaikan pengarang (Thompson, 2011: 105).

\section{Cartesian (Subjectivities)}

Cartesian bisa didefinisikan sebagai unsur subjektivitas yang dimunculkan pengarang ketika dia menulis travel writing. Dalam cerpen Paris Juni, 1988, Cartesian ini muncul dari narasinarasi yang disampaikan narator mengenai beberapa hal yang ada di Paris. Narasi ini bisa berupa sebuah gambaran yang impressive atau trustworthy. Gambaran yang impressive merupakan gambaran yang memberikan kesan mendalam. Pengarang tidak hanya menggambarkan sesuatu dengan apa adanya, tapi secara tersirat dia juga melakukan penilaian. Sementara itu, trustworthy lebih mengarah kepada penggambaran yang bisa dipercaya. Dalam hal ini, penggambaran yang dilakukan si pengarang harus jelas dan logis.

\section{a. Impressive (Yang Memberi Kesan Mendalam)}

Leila S. Chudori membuka cerpennya dengan sebuah kalimat yang tegas, namun tak terlupakan. Paris, suatu siang yang menggigit (hal. 1). Ia dengan jelas menggambarkan bahwa cerita ini berlatar pada suatu siang di Paris. Bukan siang yang biasa, namun siang yang 'menggigit', yang mengarahkan pembaca untuk berimajinasi tentang suatu siang yang teramat panas di kota Paris. Suatu siang di musim panas tentunya. Di sini Leila sudah mulai memperlihatkan unsur subjektivitasnya mengenai cuaca yang ada di kota Paris. Sebagai seorang yang berasal dari sebuah negara yang hanya mengenal musim hujan dan kemarau, Leila memberikan penilaian terhadap musim panas di Paris dengan sebentuk keluhan yang ekstrim. Padahal, bagi masyarakat Eropa yang biasa hidup dengan empat musim, tentunya mereka beranggapan bahwa udara panas di musim panas sebagai sesuatu yang normal dan tak perlu dikeluhkan karena mereka sudah terbiasa siap dengan udara sepanas apapun di musim panas. Penilaian Leila terhadap Paris dilanjutkan dalam kutipan berikut. 
"Musim panas di Eropa memang melelahkan untuk gadis Asia ini. Dia merasa lebih tentram saat Paris sudah memasuki jam 9 malam, karena matahari perlahan membenamkan diri. Selebihnya, kehidupan di Paris adalah gerak yang riuh rendah tanpa jeda. Seperti suasana jalan panjang Champs Elysee's, gadis itu merasakan bagian Paris yang ribut, arogan dan tak ramah" (Chudori, 2012: 4).

'Ribut', 'arogan' dan 'tak ramah' adalah tiga kata sifat yang merepresentasikan pikiran Leila tentang suasana di kota Paris. Tentunya penggambaran ini memberikan kesan yang mendalam karena penggambaran Leila tentang Paris sangat bertolak belakang dengan stereotipe yang kebanyakan orang percaya tentang kota Paris. Menara Eiffel yang menjulang cukup untuk mewakilkan pemikiran banyak orang bahwa Paris adalah sebuah surga, yang menawarkan kenyamanan, bukannya kegerahan. Namun Leila, melalui sebuah jalan di kota Paris yang bernama Champs Elysees, mencoba meruntuhkan semua stereotipe yang ada tentang Paris. Ia mengilustrasikan bahwa tak semua sudut di kota Paris menawarkan keindahan. Layaknya kota-kota lainnya, Paris juga mempunyai sisi gelap, yang selama ini disembunyikan di balik kemegahan Eiffel yang menyilaukan.

Selain memberikan penilaian tentang Paris dari sudut pandang orang yang berasal dari negeri dengan kultur yang sangat bertolak belakang dengan Eropa, Leila juga memunculkan penilaian tentang Paris dari orang Eropa sendiri. Hal ini tampak dari celotehan tokoh Marc, "Paris memang tak pernah menyajikan peristiwa yang biasa. Paris selalu luar biasa, seperti seorang primadona...." (Chudori, 2012: 10).

Sekali lagi, Leila memberikan pandangan kepada pembacanya bagaimana Paris selalu mendapatkan pembelaan dari bangsanya. Tokoh Marc dalam cerpen Paris, Juni 1989 merupakan representasi dari bangsa Eropa, bangsa Prancis lebih tepatnya, yang akan selalu mengagungkan
Paris dalam segala sisi. Paris adalah sebuah kota tanpa cacat bagi mereka, sebuah kota yang tak akan pernah tampil biasa. Pada bagian ini, Leila memberikan perbandingan bagaimana suatu ruang dipandang dengan perspektif yang berbeda dari individu yang juga berbeda.

\section{b. Trustworthy (Yang Bisa Dipercaya)}

Di dalam cerpen Paris, Juni 1989, Leila juga memberikan detail tentang kehidupan yang dijalankan di Paris yang memang muncul dalam kehidupan nyata. Ini merupakan salah satu bentuk selffashioning yang diterapkan Leila dengan memberikan informasi yang terpercaya di dalam fiksinya. Hal ini dapat dilihat dalam salah satu penggalan dialog dari cerpen tersebut.

\begin{abstract}
"Saya mendapatkan alamat penginapan ini dari Tuan Beamount. Apa anda masih ada sisa kamar kosong"?

"Kamu gila!" sang perempuan tua menyentak dengan suara yang parau. Cipratan ludah berdahak coklat berlompatan dari bibirnya mengenai gadis itu. "Ini Bulan Juni. Bagaimana bisa kau mengharapkan kamar di tengah kota Paris pada bulan Juni?" (Chudori, 2012: 2).
\end{abstract}

Dalam budaya Eropa, Juni merupakan waktu liburan panjang di musim panas. Akan banyak turis lokal maupun non lokal yang akan mengunjungi Paris yang merupakan salah satu kota wisata terlaris di Eropa. Di bulan ini, akan sulit mencari tempat penginapan. Fakta inilah yang dimunculkan Leila dalam cerpennya sehingga audience akan merasa bahwa cerita Leila adalah cerita yang cukup reliabel.

Selain itu, deskripsi beberapa bangunan tertentu di Paris yang cukup detail juga menjadi kekuatan Leila untuk menyisipkan self-fashioning di dalam cerpennya. Deskripsi yang muncul dalam cerpen Paris, Juni 1988 melingkupi deskripsi mengenai sungai Seine, keadaan di sekitar Menara Eiffel, dan Museum Louvre. Hal ini bisa dilihat melalui kutipan berikut. 
"Keesokan hari, Marc berhasil meyakinkan 'sang gadis Asia' untuk berjalan berdampingan menyusuri sungai Seine yang coklat dan jorok (Chudori, 2012: 12).

Gadis itu hanya berjalan di sekitar Menara Eiffel, memperhatikan para pedagang berkulit gelap mengkilat menjual berbagai kacamata" (Chudori, 2012: 8).

"Siang itu, toh sang gadis memutuskan menyusuri lorong-lorong kecil Paris. Menghampiri museum Louvre yang selalu banjir oleh Turis" (Chudori, 2012: $10)$.

Gambaran di atas merupakan ilustrasi yang sederhana dari Leila, dengan menggunakan kata yang lugas menciptakan sebuah gambaran yang jelas mengenai beberapa tempat di Paris. Melalui penggambarannya, Leila menutup segala kemungkinan spekulasi-spekulasi yang bisa muncul dari audience. Ia dengan berani memberikan kepastian mengenai apa yang ia gambarkan. Jika ditilik lagi, Leila lebih cenderung menampilkan deskripsi tentang tempat-tempat tersebut dalam bentuk narasi, bukan dalam bentuk dialog yang diucapkan oleh tokoh. Hal ini akan memberikan kesan bahwa deskripsinya itu merupakan fakta, bukan bualan belaka.

Narasi lain yang ditampilkan Leila mengenai Paris pada akhirnya akan mengindikasikan bahwa deskripsi yang ditulisnya dalam cerpen Paris, Juni 1988 didasarkan pada pengalaman empiriknya sendiri. Hal itu tampak dalam kutipan berikut.

"Selama dua hari, sang gadis memutuskan untuk menyusuri pelosok Paris dan memasuki daerah warga Paris imigran dari Afrika" (Chudori, 2012: 15).

Bagi orang yang pernah mengunjungi Paris, atau hanya menjadi seorang pelancong di Paris, tentunya tak akan menemukan adanya pemukiman di pelosok Paris yang dihuni oleh warga Paris yang merupakan imigran dari Afrika. Akan tetapi, narasi Leila mengungkapkan bahwa ia bukan seorang turis yang sekedar singgah di Paris. Lebih dari itu, ia merupakan seorang traveller yang telah melakukan observasi yang cukup mendalam tentang Paris.

\section{Janus-Faced}

Janus-Faced bisa didefinisikan sebagai aspek-aspek otobiografi yang muncul dalam travel writing. Dalam cerpen Paris, Juni 1988, JanusFaced muncul dari narator dan juga dari tokoh utama. Pendapat-pendapat yang disampaikan suara Leila yakni narator dan tokoh utama ini terangkum dalam hubungannya dengan inward scrutiny dan persona. Namun, yang perlu diingat dari hal ini adalah bahwa inward scrutiny dan persona merupakan dua hal yang menjadi bagian dari Janus-Faced, namun saling bertentangan satu sama lainnya. Inward scrutiny merupakan usaha si pengarang untuk bisa mencapai selfunderstanding. Sementara itu, persona merupakan desired identity yang ingin ditampilkan pengarang kepada audience (Thompson, 2011: 104).

\section{a. Inward Scrutiny}

Di dalam cerpen Paris, Juni 1988, terdapat sebuah narasi yang menunjukkan bahwa Leila mencoba menemukan pemahaman tentang keberadaannya di Prancis, yang direpresentasikan oleh gadis Asia yang menjadi tokoh utama dalam cerpen ini. Hal ini tampak dalam narasi berikut.

"Siang itu, hujan tumpah membasahi Paris, hingga wajah muram warganya berubah lebih cerah. Tapi, sang gadis malah bersumpah serapah karena dia tidak membawa payung atau jas hujan. Dia tak ingin berlindung dan berdesakdesakkan dengan orang-orang Paris yang selalu memandangnya dengan takjub dan heran. Entah karena warna kulitnya atau penampilannya yang terlalu biasa di kota yang selalu berdandan itu" (Chudori, 2012). 
Pada narasi di atas dapat dilihat bahwa Leila menampilkan isu perbedaan ras dengan cara yang apa adanya. Tidak terlihat adanya usaha untuk mendramatisasi. Tatapan heran dari warga Paris kepada sang gadis merupakan hal yang wajar karena struktur wajah si gadis Asia yang akan tampak mencolok ketika berada di tengah kerumunan orang-orang dari ras Eropa. Selain itu, ketidaknyamanan yang dirasakan tokoh gadis Asia dalam cerpen tersebut juga sangat masuk akal mengingat ia baru tinggal di sebuah kota yang memiliki kultur, cuaca, dan iklim yang sangat berbeda dari negara asalnya.

Di sisi lain, Leila melalui tokohnya mencoba menemukan self understanding, semacam pemahaman terhadap diriya tentang apa yang benar-benar ia inginkan dan apa yang sebenarnya tidak dia inginkan, seperti direfleksikan dalam narasi berikut,

"Kini gadis itu baru menyadari betapa ia berada di negara asing. Teritori tak dikenal. Bukan saja karena ia melihat mata warga Paris yang memancarkan dendam dan tak bersahabat. Bukan saja karena suara parau perempuan tua yang gemar menghardik itu. Ada satu suasana yang terus menerus mendesaknya agar ia merasa asing dan sendiri. Paris tak pernah manwarkan kehangatan dan tidak berpretensi menjadi sosok yang hangat" (Chudori, 2012: 14).

Kutipan di atas menunjukkan bahwa perjalanan telah memberikan proses yang mengantarkan Leila pada sebuah pemikiran yang matang. Perenungan yang berujung pada kesadaran dari gadis Asia yang menjadi tokoh utama dalam cerpen tersebut mengimplikasikan bahwa perjalanan, bagi setiap individu, memberikan proses yang lebih 'terasa' daripada hasil.

\section{b. Persona (Desired Identity)}

Di dalam cerpen Paris, Juni 1988, Leila menuliskan sebuah narasi yang cukup panjang dan menyisipkan sedikit sejarah Prancis di dalamnya. Ini dikenal juga dengan istilah anachronistic, dimana pengarang mencoba membawa isu-isu tertentu yang sudah tidak common di zaman sekarang (Batten dalam Thompson, 2011: 105). Hal ini tampak dalam kutipan berikut.

"Gadis itu berjalan di sekitar Menara Eiffel, memperhatikan para pedagang berkulit gelap mengkilat menjual berbagai cenderamata. Mereka berseru sedikit lantang, bersaing dan bahkan bersaing mendekati para pelancong untuk beberapa franc. Gadis itu selalu memahami tingkah mereka karena dia tahu kesejarahan Prancis dan negaranegara bekas jajahannya" (Chudori, 2012: 8).

Narasi di atas mengungkapkan bahwa Leila ingin menunjukkan bahwa dirinya adalah seorang yang berpendidikan. Sebagai seorang yang berasal dari negara yang sangat jauh dari Prancis, sebuah negara yang tidak pernah memiliki hubungan apapun dengan Prancis, termasuk dalam perihal kolonialisasi, Leila ingin mengukuhkan bahwa dirinya adalah sosok dari Timur yang berwawasan luas karena mampu mengetahui seluk beluk Prancis hingga ke sejarah kolonial Perancis. Kecenderungan ini juga diperkuat ketika tokoh utama dalam cerpennya (gadis Asia) menyebutkan kata 'bonsai' dalam percakapannya dengan Marc, seorang lelaki Prancis. Ketidaktahuan Marc tentang bonsai seolah semakin mengkuhkan bahwa Leila tidak hanya memahami perihal yang berhubungan dengan Barat-yang direpresentasikan oleh Prancis, namun juga hal-hal yang berkaitan dengan Timur yang direpresentasikan oleh Jepang, negara asal bonsai.

Pada bagian lainnya juga dapat ditemukan bentuk persona lainnya yang disisipkan Leila dalam cerpen Paris, Juni 1988, seperti yang tampak dalam kutipan berikut.

"Gadis itu tak pernah mengerti daya tarik apa yang membuat semua 
orang selalu menyebut Paris sebagai kota paling romantis di dunia, dan berambisi hanya ingin menancapkan diri di muka Menara Eiffel" (Chudori, 2012: 4).

Melalui narasi di atas dapat dirasakan bahwa Leila melibatkan emosinya dalam memberikan pemaparan tentang Paris. Dalam hal ini, Leila tidak mendeskripsikan dirinya secara langsung. Namun, ia memanfaatkan narator untuk menyampaikan apa yang ia rasakan tentang Paris. Ada nada sinis yang dilontarkan Leila ketika berbicara tentang Paris. Juga ada ketidakpuasan antara realita dan takhayul. Bagi Leila, Paris yang romantis hanyalah takhayul. Sementara itu, realita yang ada tentang Paris hanyalah sebuah kota yang tak disukainya.

\section{Kesimpulan}

Cerpen "Paris, Juni 1988” karya Leila S. Chudori merefleksikan satu bentuk resistensi terhadap wacana dominan, konstruksi atas deskripsi kota Paris yang terus direproduksi secara terstukrur, masif, dan sistematis sebagai kota yang indah. Resistensi muncul secara implisit pada self-fashioning yang dilakukan pengarang melalui travel writing-nya. Self-fashioning yang muncul dalam cerpen ini dilakukan dengan dua cara, yaitu Cartesian dan Janus-faced. Baik dari sisi Cartesian maupun dari sisi Janusfaced, Chudori secara frontal menuangkan satu wacana subversif terhadap deskripsi mengenai kota Paris.

\section{Daftar Pustaka}

Chudori, Leila S. 2012. Malam Terakhir. Jakarta: KPG.

Faruk. 2012. Metode Penelitian Sastra; Sebuah Penjelajahan Awal. Yogyakarta: Pustaka Pelajar.

Kumar, Akhilles. 2013. Travel Writing and Empire: A Study of Conrad's Heart of Darknessi. An International Refeered e-Journal of Literary Explorations.
Thompson, Carl. 2011. Travel Writing. London: Routledge

\section{Sumber Internet}

http://www.heraldscotland.com/ books-poetry/comment-debate/ how-romance-of-paris-inspirednovelist.117915052 